\title{
INTERNATIONAL LABOUR MIGRATION FROM INDIA, THE PHILIPPINES AND SRI LANKA: TRENDS AND POLICIES
}

\section{ROBYN IREDALE AND KALIKA N. DOLOSWALA}

\begin{abstract}
Labour migration has risen rapidly in and from the Asian region in the last two decades and countries are struggling to put in place policies that will maximise the benefits to development from migration as well as protect their migrant workers. This paper compares three countries that are at very different stages in the policy development process. The Philippines has made most progress and ranks after Mexico as the second largest sender of labour migrants in the world. The scale of these flows and the commitment to better protecting migrant workers has led to a wide range of laws and policies. Sri Lanka and India are in a position to further improve their gains from migration as well as to much better protect their citizens who have gone offshore to work. This paper highlights the current situation drawing attention to the most vulnerable groups of workers who warrant much more attention from policy makers.
\end{abstract}

\section{INTRODUCTION}

International migration in the Asian region has changed substantially in terms of its magnitude, directions and character over the last two decades. Migration into and within the region takes a variety of forms - tourists, students, refugees, family reunions, labour, business but migration for economic reasons, particularly temporary labour migration, has experienced the most rapid growth. "Asia is the developing region experiencing the most varied and dynamic types of international migration flows...' (Zlotnik 1998: 7). Labour migration is expected to become increasingly important to the countries of the region for the foreseeable future.

This paper will focus on contract labour migration - which may be organised by the governments of sending or receiving countries, by employers, by special agents or by combinations of these. Participation by the government of the receiving country is necessary for it to be regarded as regularised labour migration: otherwise, the movement should be seen as spontaneous, irregular or unauthorised. Often contract labour migration is regulated by bilateral agreements 
between sending and receiving countries or by multilateral agreements to which several states are party. The recruitment agreements or employment contracts may specify wage levels, duration of employment, working conditions and labour market rights of the workers. The agreements may also lay down obligations for the employers or public authorities to provide housing, family allowances, health care and social insurance. The recruitment agreements, together with laws and regulations of the receiving country, also define the legal status of the contract migrant with regard to residence and family reunion, as well as social, civil and political rights. Generally, the situation of the temporary workers is a highly restricted one that denies them many of the rights of citizens or permanent residents. For this reason, contract labour migration may be seen as one form of 'unfree labour' (Cohen 1987) through which a group of workers are controlled by a regime that limits their rights compared with other workers.

The current contract labour migration systems in Asia began to evolve in the 1960s around the oil-producing countries of West Asia but since the mid-1980s, rapid economic growth and declining fertility have led to considerable demand for migrant labour in countries within Asia - Japan, Republic of Korea, Hong Kong, Malaysia, Thailand, Taiwan, Singapore and oil-rich Brunei. In the 1990s, labour migration within Asia continued to grow with only a relatively minor hiccup resulting from the Asian financial crisis. A key development in recent years has been the increasing feminisation of migration: about 1.5 million Asian women were working abroad in the mid-1990s, and in many migratory movements they outnumber men.

Besides the contract or legal component, there is an equally important irregular or undocumented component. ${ }^{1}$ A recent study coordinated by the Scalabrini Migration Center in Manila states:

high levels of irregular or unauthorized migration have accompanied the rise of intra-regional migration in Southeast Asia. During the period of economic expansion, irregular migrants moved to the more prosperous economies to take up jobs vacated by the local population 
and were generally tolerated. The recession in the mid1980 s brought out concerns about the negative impacts of irregular migration. The concerns were rekindled during the economic crisis of 1997, which prompted Malaysia, Thailand and Singapore to tighten their policies against irregular migration. This meant tighter border controls, more punitive sanctions against immigration violators, and in the case of Malaysia and Thailand, undertaking massive repatriation of irregular migrants. The 1997 crisis, however, underscored that the repatriation of irregular migrants did not solve domestic unemployment. Malaysia and Thailand were confronted with a situation of high unemployment simultaneous with labor shortage in the sectors where migrants worked. Meanwhile, in the countries, particularly in the Philippines, policies and measures were also put in place to prevent irregular migration, specifically the illegal recruitment of migrant workers. By themselves, preventive approaches taken by countries of origin, and border control and sanctions undertaken by countries of destination proved to be limited in curbing irregular migration. The rise in trafficking in persons, especially women and children, has also added to the resolve of forging a regional approach to migration (Battistella and Asis 2002a: xi).

The findings of this four-country study point to 'the necessity and urgency to overcome the fragmentation of uncoordinated approaches toward migration' (Battistella and Asis 2002a: xvi). Wickramasekera (2002: 16) refers to the 'explosive growth in irregular migration' due to a combination of increased pressure to migrate combined with restrictive migration policies. It is estimated that irregular migrants comprise $30-40 \%$ of the estimated six million migrants in Asia and thus, in terms of the protection of migrant rights in Asia, this is the most important issue (Wickramasekera 2002: 16 and 21). 
The first section of this paper provides an overview of the trends and causes of less skilled international labour flows to the Gulf States and within Asia. The second part has a policy focus and compares the three sending countries in terms of the following aspects: foreign labour market development and marketing; protection of migrant workers in recruitment and employment; policy and legislative frameworks, structures and mechanisms governing labour migration; pre-departure training and orientation; remittance management and labour migration information systems and data collection, and re-integration programs. Finally, the paper examines inter-state co-operation, by means of bilateral agreements with destination countries, regional integration mechanisms and multilateral consultative processes.

\section{OVERALL TRENDS OF LESS SKIILED LABOUR FLOWS FROM SELECTED ASIAN COUNTRIES TO THE GULF STATES, AND INTRA-REGIONAL MOVEMENTS IN SOUTH AND SOUTHEST ASIA}

The economic and demographic features of the economies of Asia vary widely. For example, Vietnam's per capita GNP is US $\$ 310$ while per capita GNP in Japan is more than 123 times greater at US $\$ 38,160$. Fertility rates are also markedly different. Significant differentials also exist in these variables between the Philippines and Indonesia, on the one hand, and Korea, Singapore, Hong Kong and Chinese Taipei, on the other.

The response of the Asian economies to these significant regional spatial inequalities has been to set in motion a combination of capital and labour flows. Capital flows have taken the form of direct foreign investment and joint venture investment, generally, but not exclusively, from the more developed to the less developed countries. These inequalities have also given rise to substantial labour migration within, out of and into the Asian region. (Stahl and Iredale 2001: 1). International migration for economic reasons began to assume importance to countries of the region in the 1970s. Table 1 shows the growth from 1980-99 for Bangladesh, India, Pakistan and Sri Lanka in South Asia, Indonesia; the Philippines and Thailand in Southeast Asia and China. 


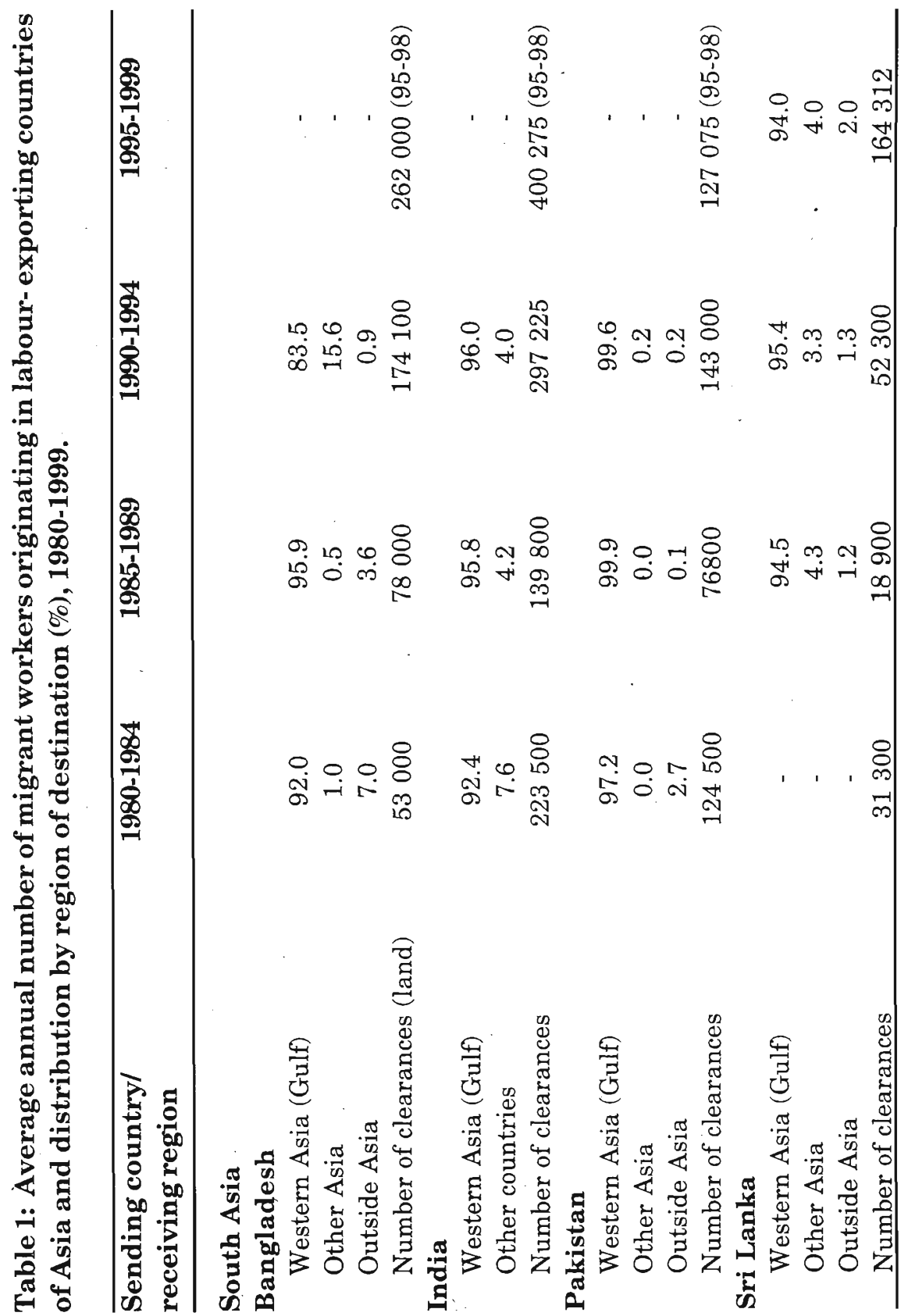




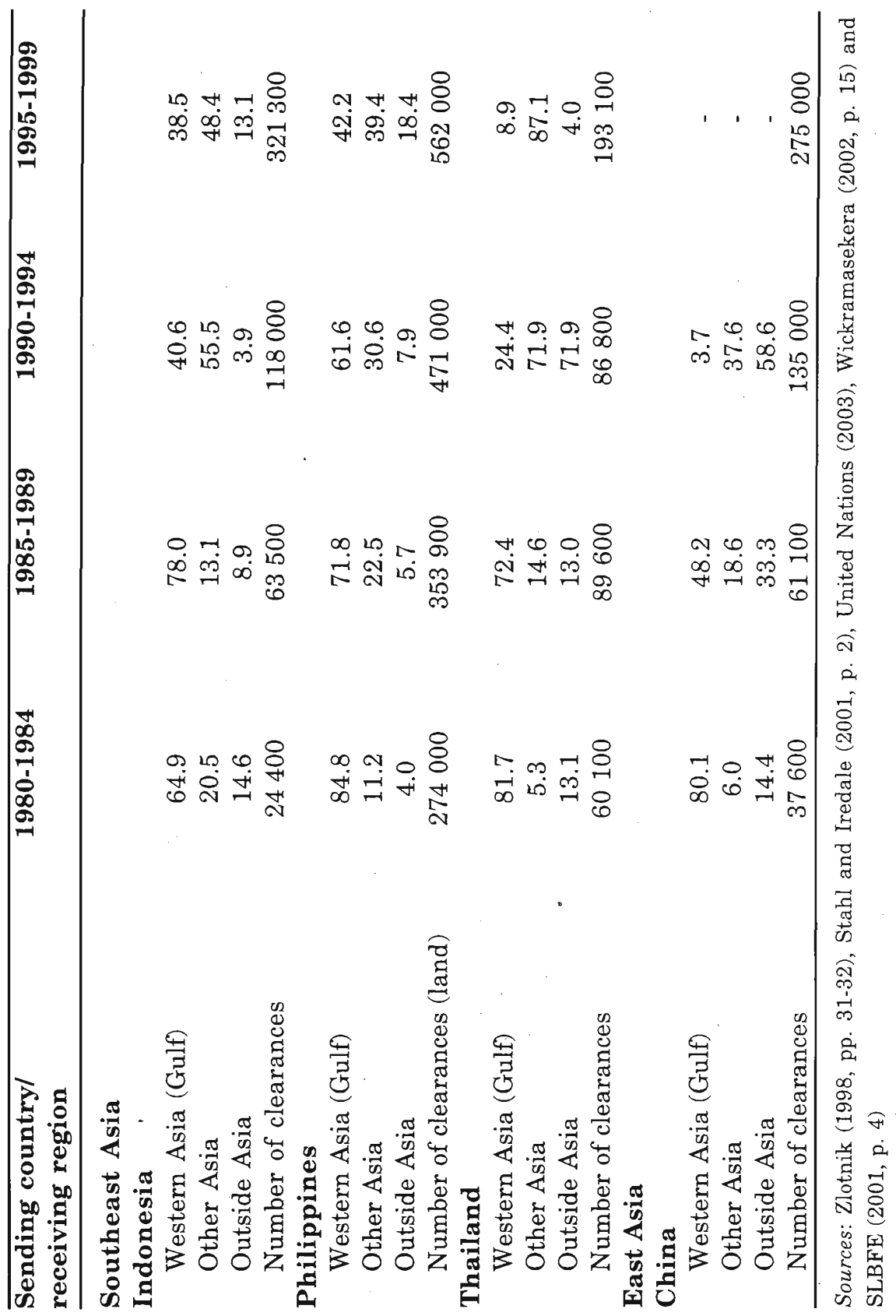


These figures exclude a considerable amount of 'irregular' migration from the countries. The importance of irregular labour migrants cannot be disputed and estimates for 1997 are shown in the following table.

Table 2: Estimates of irregular migrants in selected Asian countries, 1997.

\begin{tabular}{llcll}
\hline $\begin{array}{l}\text { Origin } \\
\text { Countries }\end{array}$ & Japan & Korea & Taiwan & Malaysia Thailand \\
\hline
\end{tabular}

\begin{tabular}{lccccc} 
Bangladesh & 5864 & 9033 & $\ldots$ & 246400 & $\ldots$ \\
Cambodia & $\ldots$ & $\ldots$ & $\ldots$ & $\ldots$ & 68468 \\
China & 38957 & 57722 & $\ldots$ & $\ldots$ & $\ldots$ \\
Indonesia & $\ldots$ & 2353 & 2700 & 475200 & $\ldots$ \\
Korea & 52854 & $\ldots$ & $\ldots$ & $\ldots$ & $\ldots$ \\
Malaysia & 10926 & $\ldots$ & 400 & $\ldots$ & $\ldots$ \\
Myanmar & 5957 & $\ldots$ & $\ldots$ & 25600 & 684676 \\
Pakistan & 4766 & 5935 & $\ldots$ & 12000 & $\ldots$ \\
Philippines & 42627 & 13909 & 5150 & 9600 & $\ldots$ \\
Taiwan & 9403 & $\ldots$ & $\ldots$ & $\ldots$ & $\ldots$ \\
Thailand & 38191 & 8200 & 6000 & 8000 & $\ldots$ \\
Vietnam & $\ldots$ & 6389 & $\ldots$ & $\ldots$ & $\ldots$ \\
Others & 72242 & 43448 & 5750 & 23200 & 92135 \\
Total & 281157 & 148048 & 20000 & 800000 & 845279 \\
\hline
\end{tabular}

Source: Scalabrini Migration Center (2000).

The trends for India, the Philippines and Sri Lanka will be explored next, with particular aspects being highlighted in each case. The aim is to compare the major issues facing these countries and the policy frameworks that have been put in place in each so far. By comparing countries it is possible for one country to learn from another and to possibly find ways to co-operate with each other. 


\section{COUNTRY STUDIES}

\section{India}

Formal labour mobility from India to the Middle East can be traced to the period when the British East India Company began to invest there (Sasikumar 2001: 57). These investments gave rise to a sudden spurt in demand for workers in clerical as well as skilled and semi-skilled manual occupations. The post-independence period has also seen large government and private investments in the Middle East and the transport of workers from India to work in these projects (Sasikumar 2001: 58).

India was one of the first countries (along with Pakistan) to respond to the demand for unskilled labour in the Gulf States that emerged as a result of the oil price rises of the early 1970s. The demand for this type of labour (i.e. construction) peaked in the 1980s and then demand-pull factors were seen to change. Reliable statistical data are not available for the last two decades, but estimates suggest that the majority of Indian labour migrants to the Middle East belonged to the unskilled and semi-skilled categories (Sasikumar 2001: 20). The annual outflow of labour from India to the Gulf rose from levels ranging between 100,000 to 200,000 during the period 1985 to 1991 , to in excess of 400,000 between 1992 and 1995 (Saini 1997: 62-63). The increasing trend was seen to reverse (or not be recorded in official figures) in the late 1990s with figures of 355,164 for 1998 and 199,552 up to October 1999. This reflected in part a shift in the patterns of labour demand from several categories of unskilled and semi skilled towards service, operations and maintenance work (Sasikumar 2001 p. 33). By far the major destination in the Middle East was Saudi Arabia (64\% between 1990-94), followed by the United Arab Emirates (17\%).

Migration originates mostly from a few states, the most important being Kerala, Andhra Pradesh, Maharashtra and Tamil Nadu (Premi 1998: 221). Nair also mentions Karnataka, Punjab, Gujarat and Goa (Nair 1998: 260). Of all of these states Kerala is by far the most important and accounts for $55 \%$ of the total outflow of migrants from 
India to the Middle East (Nair 1998: 260; Prakash 2000: 4535). Within Kerala, the majority of migrants come from the coastal districts and areas where there is a substantial Muslim population. The unprecedented high rates of return of Kerala migrants from the Gulf states during the late 1990s is seen as being due to the imposition of unskilled labour import restrictions, deterioration of wage rates for unskilled and skilled categories and competition from other labour exporting countries accelerated this return trend (Prakash 2000: 4535).

To date, labour market development and marketing has largely been dependent on the personal efforts of job seekers, kinship/personal links and some state governments. In 1977, the Kerala state government established a limited company - the Overseas Development and Employment Promotion Consultants. Presently nine such organisations exist in the states of Kerala, Tamil Nadu, Andhra Pradesh, Uttar Pradesh, Karnataka, Himachal Pradesh, Punjab and the Union territory of Delhi. There has been no coordinated national activity. 'Mostly recruiting agencies search out the new areas and avenues for deployment of Indian workers abroad' (Indian Ministry of Labour 2003).

Ostensibly, new legislation in 1983 sought to regulate private recruitment agencies through a licensing system and establish public sector recruiting agencies (Appleyard 1988: 114). The new legislation was meant to promote labour migration and protect migrants but, according to Watkins and Nurick (2002: 65), India is best characterised as having a 'laissez faire' policy with regard to migration: its policies have removed restrictions to emigration but do relatively little to support and protect migrants once they leave the country.

There is a current a proposal for setting up a Central Manpower Export Council which could take up activities such as the promotion of employment opportunities in various countries, the setting up and operation of a data bank of workers seeking employment overseas, laying down standards and guidelines for recruitment for overseas employment and monitoring the fast changing technological developments and advising the Central/State Governments and training 
institutes on redesigning their training programmes to suit the present day requirements (Indian Ministry of Labour 2003).

The protection of migrant workers' rights in both recruitment and employment is minimal. In the absence of protective mechanisms and the severity of problems experienced by women in the Middle East, the National Commission of Women has called on the Labour Ministry to increase the minimum age for female migrant workers to the Middle East. This concept has been accepted by the Protector of Emigrants and the Government is considering banning women under 35 from working in the Middle East (Mistra 2003).

No welfare fund exists at present though there is a proposal from the Ministry of Labour for the constitution of a welfare fund that will be utilised for meeting eventualities such as:

- repatriation of stranded workers;

- grant of lump sum assistance to the families of workers who die while working with foreign employers;

- grant of lump sum assistance to the workers who become permanently disabled while working with foreign employers.

No countrywide pre-migration programs exist. Some technical skills are provided to construction workers either through NGO networks or through sponsoring agencies in the receiving country. For example, some large Singapore construction firms provide technical skills and certification to migrants prior to departure. This may be driven by the more favourable tax treatment accorded by the Singapore government to companies that sponsor skilled labour from overseas rather than unskilled (Dyvadheenam 2003).

There is no government intervention in the area of remittances, in spite of the contribution of remittances to export earnings (around 10\%). Generally funds are repatriated along family, kinship lines and via accounts established by workers prior to leaving. Some Gulf countries have imposed restrictions on amounts that can be repatriated - eg Libya allows only $50 \%$ of earnings to be repatriated (Poonia 2003). Only 
those who require permission to work abroad are enumerated in the Ministry of Labour annual figures and two additional categories, those not requiring emigration clearance and irregular migrants, are not counted (Sasikumar 2001: 18).

There are no programs for the reintegration for return migrants and it is left to the NGO sector to spearhead initiatives. It is often difficult for returnees to be honest about their negative experiences for fear of being marginalised by their community (D'Sami 2000: 1). The Government of Bangladesh recently proposed and approved a bilateral agreement concerning labour migration with India. However the Government of India is yet to respond (Barniah 2001). Agreements with Qatar and Lebanon that were signed in 1989-90 'have outlasted their utility' (Indian Ministry of Labour 2003).

\section{The Philippines}

Overseas employment became an official programme in 1974 with the signing of the Labour Code by the Philippine government. It had occurred earlier but without full control by the government. Labour migrants started going first to the Middle East. Men went to work on construction sites and women mostly went as domestic workers to meet the needs of families that had become oil rich and wanted help in the house. Lowskilled workers constitute much of the country's labour surplus and by this token they are 'also the most vulnerable to abuse and exploitation, both locally and abroad' (Tomas 1998: 1). In the 1980s, increasing numbers of women were admitted to Japan and South Korea from the Philippines, Pakistan, Bangladesh and Korea to work in factories and as dancers, waitresses and hostesses. They were followed by male compatriots, as factory or construction workers. Table 1 shows the growth in contract labour migration from the Philippines from 1980.

In December 2000, the Inter-Agency Committee on Tourism and Overseas Employment Statistics estimated that 7.14 million Filipino nationals lived in 192 countries: 2.5 million as permanent residents; 2.9 million as temporary residents and 1.8 million on an 'irregular' basis. The Middle East was the major destination of Filipinos in the 
period 1970-89 but in the 1990s Asian destinations became most prominent. In the $1990 \mathrm{~s}$, more infiltration occurred into Europe. The table below shows the changing spread of destinations in 2000-01.

The major destinations of Filipino overseas contract workers (OCWs) in 2001 were 190,732 to the Kingdom of Saudi Arabia (KSA), 113,583 to Hong Kong (a decline of 6.7\%), 74,093 to Japan (an increase of $17.53 \%$ over 2000), 44,631 to the United Arab Emirates (UAE), Taiwan, Singapore (an increase of 15\%), Italy, Kuwait, Brunei and Qatar. Thus, some countries have been reducing Filipino immigration while others have been expanding. Japan and Korea are expanding, especially for women.

Table 3: Philippines deployment of overseas foreign workers, 2000-2001, by world group.

\begin{tabular}{lccc}
\hline World Group & 2000 & 2001 & \% change \\
\hline Asia & 292067 & 285051 & -2.40 \\
Middle East & 283291 & 297533 & 5.03 \\
Europe & 39296 & 43019 & 9.47 \\
Americas & 7624 & 10679 & 40.07 \\
Trust Territories & 7421 & 6823 & -8.06 \\
Africa & 4298 & 4943 & 15.01 \\
Oceania & 2386 & 2061 & -13.62 \\
Others & 6921 & 11530 & 66.59 \\
Total Land-based & 643304 & 661639 & 2.85 \\
Total Sea-based & 198324 & 204951 & 3.34 \\
Total & 841628 & 866590 & 2.97 \\
\hline
\end{tabular}

Source: Philippines Overseas Employment Agency (POEA) (2002).

Pre-departure information/education programs on migration are the major thrusts of polices to prevent irregular migration from the Philippines. The pre-departure orientation seminar, a mandatory one- 
day briefing provides information on documentation, rights and obligations under the employment contract, what to expect on arrival, remittance advice, where to go in times of crisis and health and occupational safety (Dimapilis-Baldoz 2003: 7). Though stock estimates suggest that the irregular component is substantial (1.8 million in 2000), irregular migration is smaller than the population of legal migrants, irregular migrants are widely distributed and about half are female (Battistella and Asis 2002b: 36-8). In contrast to other countries, the major piece of legislation, the 1995 Migrant Workers and Overseas Filipinos Act, covers irregular migrants. The 'victims of illegal recruitment and related cases can avail of legal assistance from Philippines Overseas Employment Administration (POEA)', though it is difficult to measure the 'effectiveness of the redress and protection provided by the government.... Initiatives for their protection aim to bring them into the realm of regular migration (Battistella and Asis 2002b: 43-45).

The next table shows the occupational breakdown of new legal hires from 1992 to 2000 . While the number of documented males has declined, the number of women has increased from 107,585 to 174,768. There were 23,146 more females in professional, technical and related occupations, 20,476 more female composers, musicians and singers and around 20,000 more domestic workers over this period.

This gender breakdown of new land-based (i.e. does not included seafarers) deployments shows an increasing proportion of females, from $50 \%$ in 1992 to $70 \%$ in 2000, and $73 \%$ in the first half of 2002 (POEA 2002). Data from the POEA shows that female professional and technical workers represented $42.3 \%$ of total female migrants and $85 \%$ of this category between January to October 2002. However, the importation of female 'entertainers' to various countries, especially Japan and South Korea, is very noticeable. Most such workers come from the Philippines and Thailand. In 1995, as a result of protests from Filipino NGOs (especially DAWN) about the exploitation of women as 'sex workers' in Japan, regulations came into effect in the Philippines that stated that entertainers must be at least 23 years old, have one year's performing experience at home and provide evidence of training 


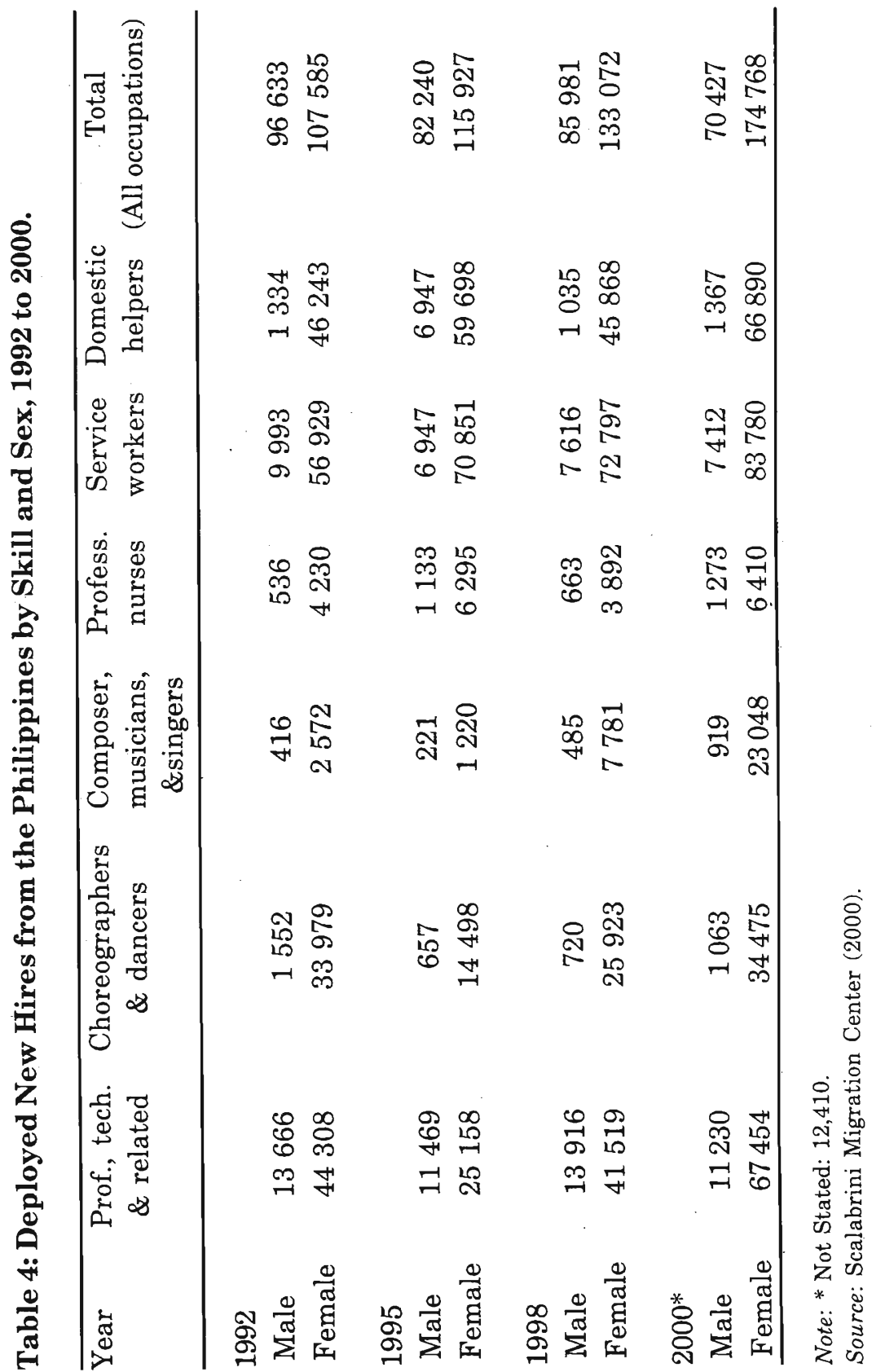


as an entertainer. In 1996, 42,500 Filipinos were found to be overstayers in Japan and from September 1996, it became more difficult to obtain an extension of an entertainment visa. The Japanese Government had found that $93 \%$ of entertainers were attending to customers as hostesses or guest relations officers. This was an instance of the two governments co-operating to protect the situation of Filipino entertainment industry workers.

In the short term the changes led to entertainers being recruited from other countries for the Japanese market. These workers were much less protected by their own governments and continue to be exploited. In the late 1990s, the Philippines government sought to alleviate the problem by providing [mostly] the women with four-week training courses as 'entertainers' (singers, dancers, musicians, etc) and then classifying them as 'skilled' workers. This enabled them to be admitted to Japan as skilled immigrant workers but to continue to go into the entertainment/sex industry. This 'solution' has come under increasing criticism as it is seen for the cynical exercise that it is.

Domestic maids are increasingly being recruited, particularly in the Philippines, to facilitate the labour market participation of women in Hong Kong, Singapore, Malaysia and other Asian countries. About $80 \%$ of foreign domestics (around 150,000) in Hong Kong are from the Philippines. In 1993, there were an estimated 81,000 foreign domestic servants in Singapore, 50,000 of whom were from the Philippines, 17,000 from Sri Lanka and 10,000 from Indonesia (Castles and Miller 1998: 152). By 1998, the figure had reached 100,000. Frequent cases of abuse were reported to the Philippine authorities, leading to a ban on recruitment in 1987 . This, however, was circumvented by the Singaporean authorities who admitted Filipinas as tourists and then gave them work permits. Public concern in the Philippines came to a head in 1995 when a Filipino maid, Flor Contemplacion, was hanged in Singapore, after being found guilty of murder. The Philippines government banned the migration of domestic workers to Singapore but this ban was soon lifted. 
Malaysians can hire domestic servants from abroad but there is a two-tiered system: only those with a monthly income of $\mathrm{M} \$ 10,000$ or more can hire maids from the Philippines and Sri Lanka, while those with a monthly income of $\mathrm{M} \$ 3,000$ to $\mathrm{M} \$ 10,000$ can hire domestics from Indonesia, Thailand and Cambodia. The maid must be between 25 and 45 years of age, able to converse in Bahasa or English and must obtain a work permit endorsement within a month of arrival (Migration News 1998).

There is a clear hierarchy amongst maids, with Filipinas being the most expensive and at the top in terms of desirable features (English speaking, often very well educated). However, they are also very articulate, well networked and organised and this is leading to their displacement by cheaper and less well versed maids in some places. Since 1 July, 1997, there has been an increase in the rate of termination of Filipino maids in Hong Kong for 'unsatisfactory performance' and this means that employers do not have to meet end-of-contract payments. The Philippine Consulate in Hong Kong recently commenced orientation seminars for new arrivals in 1998 to inform women of their rights and to try to alleviate this problem.

Many Filipinos are tertiary educated and migrate to work in low skill jobs, thereby experiencing a de-skilling process $-28 \%$ of temporary migrant workers have a college degree (Alburo and Abella 2002: 8). The Philippines government has been trying to find appropriate contract work for its overseas contract workers (OCW) but generally they are only hired for low skill jobs.

The migration of Filipinos to Europe for work also stepped up in the 1990s. Data from the OECD show that Filipinos are mostly likely to migrate for work to Italy and Spain and that these migration flows, aspecially of females, are 'linked to the development of the domestic service and health-care sectors' (OECD 2001: 67). Filipinos (61,000) comprised the largest Asian group in Italy in 1999, followed by Chinese, Sri Lankans and Indians, and the second largest group in Spain, after the Chinese (OECD 2001: 67-68). 
In $2002,73 \%$ of departees were women. Whereas the migration of females often brings them greater autonomy and freedom, there is a disturbing aspect to the migration of Filipino women: their concentration in domestic services and entertainment. Being unprotected sectors, the occupational hazards associated with domestic work and entertainment have cast serious doubts on the positive impacts of migration (e.g., Cox 1997; Shah and Menon 1997). Moreover, the rising trend in trafficking in women and children has magnified the risks of migration for women, threatening their fundamental human rights (Asis 2001: 25).

The level of remittances is such that overseas employment is a key strategy in the Philippine Development Plan. The actual investment generated from remittances is not easily measurable but it is assumed that it will lead to increased living standards and increased consumption, increased money for education and for businesses. This money eventually finds its way back into the economic system. Moreover, it is an important survival strategy for many people living in poverty. The wage differentials between local and overseas wages makes it abundantly clear why so many people want to work abroad or are chosen by their families to work overseas. For example, Tomas (1998: 22) provides data to show that the wages of domestic helpers are $1744 \%$ more as OCWs, clerks' overseas wages are $427 \%$ higher than domestic wages and waiters', plumbers' and labourers' overseas wages are three times higher than local wages.

This profile of Filipino workers abroad as well as the sheer numbers that have been or are affected by overseas labour migration (totalling around 10 million over time) have pushed the Philippines government to make ever greater efforts to protect their OCWs. By the 1980s, the Philippine government had created two agencies: the Philippines Overseas Employment Administration(POEA) to do market promotion and development, regulation of the industry through a system of licensing and monitoring, and documentation, processing and deployment of workers; and the Overseas Workers Welfare Administration (OWWA) to cover welfare and protection issues. Various forms of illegal recruitment, contract substitutions, delayed payment or non-payment of wages, harsh working and living conditions are still 
experienced, especially by women. The over-representation of women among problematic cases monitored by the Overseas Workers and Welfare Administration (OWWA) underscores their greater vulnerability. Women are often employed in unprotected worksites and gender-based discrimination, especially gender-based violence, is rife. The major strategies to promote Filipino workers overseas are: the dispatch of overseas missions, development and production of promotional materials, direct mailer campaigns, market research, liaison with diplomatic staff and participation in international conferences/forums on migration. Additionally, initiatives such as client referral assistance programs, industry liaison and negotiations for bilateral and multi-lateral agreements are also used (Dimapilis-Baldoz 2003: 8-9).

The prevalence of the phenomenon and the emergence of many non-government groups (NGOs), both within the Philippines and offshore, to highlight the needs and problems of OCWs ensures that the issue is kept at the forefront of the government's agenda. The government has progressed much further along the route of monitoring than any other labour exporting country. The POEA sees government control as essential for controlling conditions of employment: it has bilateral agreements or is seeking such agreements with 34 countries/ economies. The Philippine Overseas Labour Offices (POLO) maintains around 45 labour attaches in about 32 countries sites of destination of OFW's to provide counselling, legal assistance, conciliation and liaison services to workers in distress. According to POEA information they also link up with the home offices of the Department of Foreign Affairs and Department of Labour \& Employment (DOLE) to enforce obligations of recruitment agencies and employers over welfare issues (DimapilisBaldoz 2003: 7).

It develops 'model employment contracts for different countries and different occupations that include basic standards and requirements. Rodriguez (2002: 23-24) questions whether by using model contracts as the basis for workers' final contracts 'the state, inffect, plays a role in disempowering workers'. For example, some contracts list participation in trade union activities as a legitimate reason for a worker's termination 
and favour employers in terms of the handling of disputes. Rodriguez argues that this makes for a docile labour force. The Philippines government and the International Labour Organisation (ILO) exert continuous pressure on labour-receiving countries to sign the UN Convention on the Protection of the Rights of All Migrant Workers and Their Families. Unfortunately, many are still not signatories.

In a critique, Santiago (2003: 217) states that the 1995 Migrant Workers and Overseas Filipinos Act's statement of policy 'is pompous to the point that it renders impossible the meaningful implementation of the law and risks exposing the government to criticism of paying mere lip service to the welfare of overseas Filipino workers. Updated statistics on cases involving Filipino migrant workers and the pronouncement by the Philippines highest court in the case of Prieto vs. National Labor Relations Commission affirm the fact that even the most well-meaning government institution will not be able to implement the Act's avowed policy'. Information provided by POEA (2003: 5) states that 'maltreatment and exploitation at the job sites...is attributable to a conflux of factors that may include lack of preparation prior to deployment, host countries' prejudicial labour policies due to sociocultural considerations and weak welfare protection mechanisms for foreign workers that somehow reinforce the recruitment agencies' and employers' exploitative practices'.

The very active role of Filipino NGOs both at home and abroad is a unique feature. In the absence of governmental protection and regulation, NGOs and civil society have attempted to address the gaps and problematic issues of migration, including on-site organising of migrant workers as well as initiatives and services to assist with the re-integration of migrant workers. This reintegration assistance builds on the livelihood skills and entrepreneurship training, business development assistance such as consultancy financing, project planning and management, credit and micro-finance initiatives of public authorities. Further the OWWA has on site re-integration preparedness programmes in more than 20 countries and 27 major cities. In December 2002 President Gloria Macapagal-Arroya instructed OWWA-DOLE to establish 25 Family Welfare Offices (FWOs) to link OFW families with 
government and NGOs in support of the efforts at organising them into an audible and visible representative sector of society. The FWOS shall be tasked with the development of new programmes and improvement of existing programmes for OCWs and their families, research, monitoring and evaluation and further development of the Philippine Reintegration Program (Dimapilis-Baldoz 2003: 10-12).

The Philippines has entered into 12 manpower agreements with host countries of Filipino labour. Most of the agreements with Middle East countries focus on strengthening areas of co-operation in the fields of labour, employment and manpower development and the enhancement of the welfare, well-being and workers' rights. European agreements are more focused, aimed at particular sectors of employment such as health professions in the UK and Norway. In recent years, the Philippines has veered away from general agreements towards more focused instruments which it claims are easier to negotiate and operationalise (Dimapilis-Baldoz 2003: 13).

\section{Sri Lanka}

Table 1 shows the very strong orientation of Sri Lankans towards the Gulf States since 1985. Labour export commenced and continues as a means of alleviating unemployment. The overwhelming dominance of the Gulf States has continued throughout the 1990s though more recently attempts have been made to send more people to other Asian countries. Markets are now being sought in Europe and Italy recently granted 1,000 direct employment opportunities in the fields of tourism, building construction and the domestic sector to Sri Lankan workers, as a result of a request by Sri Lanka's Employment and Labour Minister. This was the first Asian country to be granted a special job quota and the move is hoped to put 'a stop to human smuggling'. ${ }^{2}$ In future, $10 \%$ of the jobs granted by the Italian government will be reserved for unemployed graduates and Sri Lanka hopes to pick up $10-15 \%$ of jobs offered by European countries for its unemployed graduates (Asian Migration News 2002a). 
The table below shows the increasing dominance of female labour migration in Sri Lanka Bureau of Foreign Employment (SLBFE) official figures. During the 1995-2000 period, of the 701,867 female labour migrants $90 \%$ occupied 'housemaid' and 'unskilled' categories although this percentage was falling slightly toward the end of the period (88.8\% in 2000 against $95.2 \%$ in 1996). Between 1995 and 1999, the top three destinations for labour migrants from Sri Lanka were Saudi Arabia (37.3\%), Kuwait (23.3\%) and UAE (16\%), and together they received over three quarters of all labour migrants (SLBFE 2001: 4).

The Sri Lanka Bureau of Foreign Employment (SLBFE) was established in 1985 under Employment Act No 21. The main objectives of the SLBFE are the promotion of foreign employment, sound management of (the) foreign employment field and ensuring the welfare and security of the migrant employees and their families (Ministry of Employment and Labour 2002a: 164).

Table 4: Departures from Sri Lanka for foreign employment by sex, 1981-2000.

\begin{tabular}{lcccc}
\hline Year & Male & \% of total & Female & \% of total \\
\hline $1981-1985$ & 85490 & 60 & 69263 & 40 \\
$1986-1990$ & 60419 & 50 & 69668 & 50 \\
$1991-1995$ & 131844 & 31 & 301826 & 69 \\
$1996-2000$ & 303781 & 31 & 701867 & 69 \\
2001 & 59751 & 32 & 124137 & 68 \\
\hline
\end{tabular}

Source: SLBFE (2001, pp. 1-2), Ministry of Employment and Labour (2002b).

Section 15 of the Sri Lanka Bureau of Foreign Employment Act No 21 of 1985 (hereafter referred to as the Act) identifies in S15(a) that one objective is 'to promote and develop employment opportunities outside Sri Lanka for Sri Lankans'. Part VIII S54 calls into being the Association of Licensed Foreign Employment Agencies (ALFEA), every licensee being a member. One function of this association is 'to make 
recommendations to the Bureau in regard to the promotion and regulation of employment outside Sri Lanka (S55(c))'. Part III of the Act, S20 outlines the ability of the Sri Lanka Bureau of Foreign Employment (SLBFE) to enter into agreements with foreign governments and with foreign employers and agencies. Further, the Bureau may support and assist licensees in their promotional activities and sponsor visits abroad by representatives of these licencees.

The government's Bilateral Cooperation Unit also collects information from missions on job opportunities. Active efforts continue to be made by the government to expand markets in the Middle East and in Japan, South Korea and Cyprus (Watkins 2002: 66). In order to monitor labour market developments in labour importing countries, missions also send monthly reports back to the SLBFE (Ruhunage 2002). There is a new Draft National Employment Policy, according to Athukorala (Ministry of Employment and Labour 2002b), the vision of which is 'to adopt a pro-active approach to identifying global employment opportunities and uplift the image and skills of migrant human capital by providing them appropriate training to enhance their competitiveness'.

SLBFE data are based on registration of migrant workers. Additionally, the immigration/emigration card system in place at the airport represents a data collection system. Registration was made compulsory in 1995 and SLBFE information suggests that irregular recruitment declined to around $10 \%$ following compulsory registration (SLBFE 1999: 3). One of the drawbacks in using the registration information is that it does not account for people who registered and then did not leave, thought to be in the vicinity of 5-10\% of registrations (Resource Development Consultants 1997: 26). Further, Soysa (2002a: 4) states that it is reported that $30-40 \%$ of persons leaving for employment abroad do not register with the Foreign Employment Bureau. It is claimed that they prefer not to do so, as otherwise they are compelled to pay very heavy registration fees which are levied on the basis of procurement charges permitted under Section 51 of the law'. Additionally, the ability to leave to take up a job in another country is provided for under Sri Lanka's Constitution. 
The job of protecting migrant workers in recruitment and employment is largely in the hands of licensed agents. Section 34 of the Act states 'A licencee shall not charge any fee, otherwise than as provided in Section 51 for providing or securing employment for any person in any country outside Sri Lanka' (SLBFE 1985: 13) and Section 51 outlines the charges. But research from a number of sources has identified that migrants often pay far in excess of the government stipulated fee (Yapa 1995: 134; RDC 1997: 71). The main reason for this was identified as being quick placement. This excessive fee payment implies that many placement agents are breaching the Act \& regulations but only three cancellations of registration by the SLBFE of 522 registered agencies up to August 2002 (Ministry of Employment and Labour 2002a: 164) suggests that ensuring agents comply with this requirement, is a complex issue and not of the highest priority.

The role of agencies is increasingly becoming the dominant channel for overseas labour recruitment. All agents must belong to the Association of Licensed Foreign Employment Agencies (ALFEA). The association's responsibilities under the Act include mediating disputes between licence holders, establishing a code of conduct, advising and assisting the SLBFE on promotion and marketing.

Labour attachés are posted in six Middle Eastern countries and Labour Welfare Officers have been appointed to 12 countries (Ministry of Employment and Labour 2002b): Ridadh (2), Jeddah, Abu Dhabi, Dubai, Kuwait, Jordan, Lebanon, Qatar, Oman, Singapore, Malaysia, Maldives, South Korea (Ruhunage 2001: 1). Missions generally concentrate on welfare-related issues but the ability to assist migrants in court procedures is restricted due to funding issues, language barriers and the volume of cases (Resource Development Consultants 1997: 77). In 1996, 314 Sri Lankan women sought protection in camps in Lebanon \& Kuwait and 3,000 were imprisoned in the Gulf States (RDC 1997: 77). In 2001 , there were 7,927 complaints received by the SLBFE, mostly from housemaids, and Sri Lanka has set up safe houses in some countries 'to provide shelter to run away migrant workers' (Ministry of Employment and Labour 2002a). The Welfare Fund is dependent on a 
levy of US\$25 that is imposed on overseas employers for each worker from Sri Lanka.

Though a training stamp is now required on passports for migrant workers to be able to leave the country, pre-departure training is mostly restricted to awareness building and basic household skills and is targeted at housemaids. Twenty centres affiliated with the SLBFE and seven centres affiliated to registration agencies provide the training. Five-day training for housemaids was made compulsory from April 1996 and was later extended to 12 days for the Middle East sector and 21 days for all other countries. Training also occurs for workers going to Korea. Training is conducted on: counselling and guidance; vocational skills; travel documents and procedures; financial management and banking; social relations and family welfare; possible worksite problems and solutions, and language skills. NGOs, such as the National Workers Congress, also run additional training programmes - such as an awareness programme for domestic migrants that seeks to assist migrant workers and families make decisions and avoid pitfalls (Weerasinghe 2000: 86). The Vocational Training Institutes, under the Ministry of Vocational Training, are at present targeting the more skilled overseas labour market but this affects only a very small percentage of migrants.

There is limited participation of local banking representatives in pre-departure training to raise awareness of remittance management options (eg foreign currency accounts, fixed deposits etc) and subsidised loan schemes. Representatives of some of the banks are posted overseas and work directly with the exchange house, principally in locations where there are large numbers of Sri Lankans employed. These representatives help in the processing of remittances and provide the required guidance and support to the remitter (CENWOR 2001: 6). The linking up of housing loan facilities to Non Resident Foreign Currency (NRFC) accounts, attractive lottery and gift schemes and aggressive promotional campaigns has ensured that savings are channeled to NRFC accounts (CENWOR 2001: 20). There is evidence to suggest that most of the remittances sent back to families are not used for development, building or empowerment. Alcohol abuse and gambling are social 
problems that are heavily impacting on the effectiveness of foreign employment (CENWOR 2001: 21). The development of programmes and strategies to address these areas in relation to remittance management are still at a stage of infancy.

A significant proportion of remittances are sent through informal and unreliable channels, such as unregistered agencies and individual operators. The reasons given for the widespread use of the informal system are the lack of or unfamiliarity with formal banking facilities, and the overly restrictive and inefficient banking system in the region.

Figure 1 shows that private remittances comprised approximately $20 \%$ of Sri Lanka's total foreign exchange (FX) earnings during the decade to 2000, however a slight downward trend has been experienced recently (22.3\% in 1991 to $20.9 \%$ in 2000). Middle East remittances during this period increased, rising from $52 \%$ of total private remittances in 1991 to $63 \%$ in 2000 (SLBFE 2001).

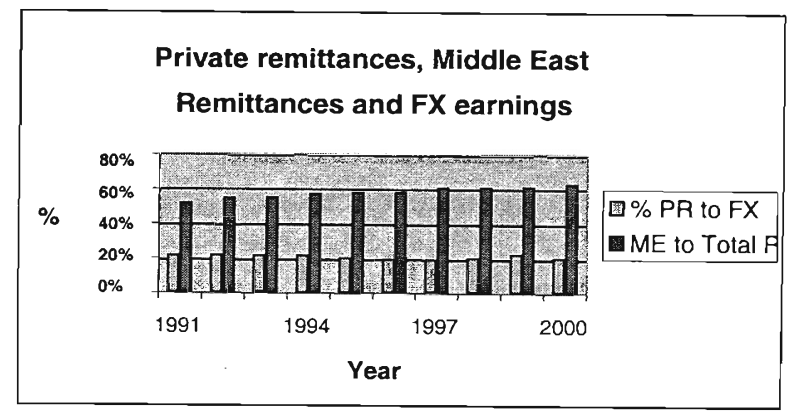

Source: Calculated from data supplied to the authors.

\section{Figure 1: Private remittances as percentage of foreign exchange earnings and proportion of Remittances from the Middle East.}

Financial and operational assistance for self-employment, and small enterprise concessionary loans are available to returning migrants. However, in comparison to the volumes of labour migrants, the disbursement of funds ùnder these schemes accounts for less than $1 \%$ 
or return migrants. Soysa (2002b) suggests that one of the principal reasons for this is that returnee migrants are reluctant to enter into another debt cycle. There is also inadequate assistance other than financial. While a 1995 ILO/ARTEP study found that income levels of migrant families have increased from pre-migration levels, the sustainability of the new standard of living has not been conclusively established (CENWOR 2001: 22).

Section 20(a) of the Act provides for the Bureau to enter into agreements with foreign governments (SLBFE 1985: 8) but to date no government-to-government agreements have been established. Private sector manpower associations have entered into MOUs but these presently only cover labour recruitment i.e. minimum salaries, conditions of employment and the obligations of the Sri Lankan agency. The intention is to have these MOUs with countries such as Jordan, Qatar, Kuwait and Malaysia by February 2003.

\section{GROUPS OF MIGRANT WORKERS REQUIRING SPECIAL FOCUS}

It is generally agreed that the three most vulnerable groups of migrant workers throughout Asia are irregular workers, female workers and trafficked people. These categories are not necessarily mutually exclusive but this section will focus on these three groups as the ones needing the most urgent and comprehensive attention.

\section{Irregular migrant workers}

In April 1999, the Royal Thai Government, in cooperation with IOM, organised an 'International Symposium on Migration: Towards Regional Cooperation on Irregular/Undocumented Migration' in Bangkok. The Bangkok Declaration on Irregular Migration 1999, adopted by the 18 participating (sending and receiving) states, provides a framework for future regional cooperation in combating irregular migration and trafficking. It also contains an agreement that countries cooperate regionally and individually take strong action to stamp out the most harmful form of irregular migration, trafficking (dealt with below) (Klekowski von Koppenfels 2001: 13). 
Employer sanctions have a limited effect for a variety of reasons but mostly because employers and foreign workers become dependent on each other (Ruhs 2002: 58). Moreover, while all countries have some form of forced return policy the deportation of irregular migrants seems to have little effect. The best means to protect the welfare of migrant workers is to preclude, by all means possible, the existence of opportunities for their exploitation by unscrupulous agents or employers.

Both authorised and unauthorised migrations have similar determinants and processes and the migrants are similar, except in terms of access to channels of migration. The high costs of migration, the inflexibility and/or brevity of some contracts and the absence of opportunities to migrate often lead to a growth in the number of irregular migrants. Thailand and Malaysia host the largest numbers of irregular workers in the Asian region and until these countries adapt their migration intake programmes to meet the needs of their economies, irregular migration will continue to thrive.

After analysing many labour migration programmes, Ruhs (2002: 58-59) concludes that one policy principle that should be followed in all temporary labour programmes is that irregular 'migrant workers who have been employed in the host country for a certain number of years without being detected and deported' should be regularised. It is accepted that this is a highly controversial policy option and not accepted by many governments. It is already happening in Italy and Spain but the willingness to provide permanent settlement for temporary migrant workers is limited in Asia or the Middle East. In the event that regularisation is not an option, the safe return of irregular migrants should be guaranteed.

The long-term solutions to irregular migration are to open up more opportunities for regular migration and reduce the pressures for emigration. In the meantime, the UN Convention of the Rights of All Migrant Workers and Their Families 1990 can now come into operation and countries should be encouraged to ratify. If it is translated into domestic legislation it will ensure greater protection for irregular 
migrants. The ILO's core conventions also cover the rights of irregular and regular migrants and countries could be encouraged to adhere to them.

\section{Female migrant workers}

There is a growing body of literature on women in migration and it is attributable to a number of factors: the feminisation of international migration, especially in Asia; the distinct patterns of movement of women (domestic employment and moving/being trafficked for prostitution); and increased education levels for women and girls, resulting in many more politically active and outspoken female activists in various countries of Asia. In the Philippines, in particular, the role of articulate women in highlighting the plight of many of their sisters and their capacity for networking with women in other countries, both through various NGOs as well as even more informally (the internet), has led to an upsurge in pressure in relation to the situation facing contract women workers who are overseas.

The major problems identified are:

- Women's live-in domestic work continues to be seen as an extension of household work and therefore not properly valued or included under Employment Acts (Piper et al. 2002). This leads to a lack of protection on working and living conditions.

- In the case of sex work, the discussion needs to recognise the diverse, complex and contradictory processes at work. Gross economic inequalities result in different degrees of 'choice' and/or 'constraints' and the tendency to use either a 'victimisation' or an 'agency' perspective often masks the complexity of the conditions under which women work. Human rights advocacy and policy making in this area needs to pay attention to the specific contexts in which migration for sex work occurs.

There is now a wider understanding of the multiple disadvantages and potential for exploitation and abuse that many migrant women workers experience. Women are often faced with both 
direct (as above for domestics) and indirect (structural) discrimination and this requires attention at the global level. The issue of sex and race discrimination towards women from developing or labour sending countries in Asia is endemic. Banning such migration is not a longterm solution as this often leads to irregular migration, especially trafficking.

\section{Trafficked persons}

The trafficking (involving some element of coercion or force) of women and children, often for commercial sex and other exploitative and abusive purposes, is rampant in Thailand and the neighbouring countries of Vietnam, China, Bangladesh, Nepal, India and Pakistan. NGOs were the first to highlight these practices but now the Thai, Philippines and other governments, IOM, ILO, UNESCO and other bodies too have become involved.

The Manila Process (IOM Regional Seminar on Irregular Migration and Migrant Trafficking in East and South-East Asia) held in 1996 was mainly an information-sharing process. A second regional conference (referred to above) followed in Bangkok in 1999. The outcome, the Bangkok Declaration, called for a regional mechanism and strong national action for dealing with traffickers. The countries mostly pushing for this were the receiving countries, such as Australia, Japan and the Republic of Korea. But after almost four years, much work still needs to be done on the regional mechanism and individual governments still need to introduce strong laws for apprehending and punishing traffickers. The root causes of both irregular and regular migration received much less attention in the Bangkok Declaration, in spite of the emphasis given to this aspect by sending countries.

Other initiatives have been taken in relation to trafficking, including The Asian Regional Initiative Against Trafficking in Women and Children (ARIAT), the Asia Pacific Consultations (APC) and a 1997 ASEAN Declaration on Transnational Crime. Derks (2000) provides a very useful summary of the policy and program responses taken to combat trafficking in Southeast Asia in the 1990s. 


\section{CONCLUSION}

'Asian countries have a long way to go to ensure adequate protection to migrant workers who are contributing in a major way to the economic development and prosperity in the region', according to Wickramasekera (2002: 32). This paper has demonstrated that there are good national policy options already in place in the Philippines and they could serve as a model for improving other countries' policies. India and Sri Lanka have some policies and laws in place but many of their workers are not adequately protected offshore.

The greatest weakness in the region lies in the lack of collaboration both between sending countries and between sending and receiving countries. Regional mechanisms that may provide scope for better labour migration programmes in the future need to be developed so that sending countries stop undercutting each other and work together to guarantee the rights and conditions of their workers. Receiving countries have played one sending country off against another and in this way have shown considerable disdain for migrant workers from Asia. None have signed the United Nations International Convention on the Protection of the Rights of All Migrant Workers and Members of Their Families that came into force on 1 July 2003. They are unwilling to settle family members of migrant workers or to extend a full set of rights to 'irregulars'. These seem intransigent problems at this point but the Philippines is an example of a country that has been able to attain a reasonable situation for most of its migrant workers.

\section{Notes}

1 The term 'irregular migration' is used as the preferred term. It is more neutral and it does not criminalise migrants. 'Undocumented migrants' is often not accurate as many irregular migrants carry documents.

2 Recent experience shows that such smuggling has not ceased, however (Sri Lanka source). 


\section{References}

Alburo, F. A. \& Abella, D. I. (2002). 'Skilled Labour Migration from Developing Countries: Study on the Philippines', International Migration Papers 51, Geneva: International Labour Office.

Appleyard, R. ed (1998). Emigration Dynamics in Developing Countries, Volume One: South Asia. Aldershot: Ashgate.

Asian Migration News (2002). 'Italy offers jobs', accessed 30 November, http://www.smc.org.ph/ smc/amnews/amnews.html

Asis, M. 2001, 'Country Study 1: Philippines', in S. Chantavanich, C. Willie, K. Angsuthanasombat, M. Asis, A. Beesey and Sukamdi, Female Labour Migration in South-East Asia: Change and Continuity, Bangkok: Asian Research Centre for Migration, Chulalongkorn University, pp. 23-93.

Barniah, N. (UNIFEM) (2003). Personal Communication, Delhi, 8 January.

Battistella, G. \& Asis, M. (2002a). 'Executive Summary', in G. Battistella and M. Asis (eds), Unauthorized Migration in Southeast Asia, Report Submitted to The Ford Foundation, Manila: Scalabrini Migration Center, pp. xi-xvi.

Battistella, G. \& Asis, M. (2002b). 'Irregular Migration: The Underside of The Global Migrations of Philippines', in G. Battistella and M. Asis (eds), Unauthorized Migration in Southeast Asia, Report Submitted to The Ford Foundation, Manila: Scalabrini Migration Center, pp. 33-120.

Castles, S. \& Miller, M. (1998). The Age of Migration, Second edition, Basingstoke, UK: Macmillan Press.

Centre for Women's Research Sri Lanka (CENWOR) (2001). Channeling and Utilisation of Remittances of Migrant Domestic Workers, Report of Discussion Meeting held on 5 April. 
Cohen, R. (1987). The New Helots: Migrants in the International Division of Labour, Aldershot: Avebury.

Derks, A. (2000). Combating Trafficking in South-East Asia: A Review of Policy and Programme Responses, International Organization for Migration (IOM), Migration Research Series, No. 2, Geneva: IOM.

Dimapilis-Baldoz, R. (2003). Data contained in Completed Questionnaire submitted to IOM for Labour Ministers' Consultations held in Colombo 1-2 April 2003.

D'Sami, B. (2000). 'India's pre-departure, post arrival and reintegration programme' Paper presented at the Preparatory meeting for Regional Summit on Pre-Departure, Post Arrival \& Reintegration Programs, 27/ 2/2000-29/2/2000, Kuala Lumpur.

Dyvadheenam, T. (2003). Personal Interview, New Delhi, 9 January.

Indian Ministry of Labour (2003). 'Ministry Of Labour At A Glance In The New Millennium: International Migration Of Indian Workers', http://labour.nic.in/glance/molglance.html\#MIGRATION, accessed on 11 January, 2003.

Klekowski von Koppenfels, A. 2001, 'The Role of Regional Consultative Processes in Managing International Migration', IOM Migration Research Series, No. 3, Geneva: International Organization for Migration.

Migration News (1998), (various dates), available at http:// migration.ucdavis.edu

Ministry of Employment and Labour (Sri Lanka) (2002b). Data contained in Completed Questionnaire submitted to IOM, 24 December.

Ministry of Employment and Labour (2002a). Annual Report, Colombo, Sri Lanka. 
Mistra, M. (2003). Personal Communication, UNDP, Delhi, 8 January.

Nair, P. R. G. (1998). 'Dynamics of Emigration from Kerala: Facts, trends, patterns and policies' in R Appleyard (ed) Emigration Dynamics in Developing Countries, Volume One: South Asia. Aldershot: Ashgate.

OECD (2001). Trends in International Migration, SOPEMI Annual Report, Paris: OECD.

Philippines Overseas Employment Agency (POEA) (2002). Table on website, www.poea.gov.ph/stats, accessed on 12 December.

Piper, N., Yamanaka, K., Asis, M. and Iredale, R. (2002). "Report on Major outcomes of Gender, Migration and Governance in Asia" Australian National University, 5-6 December, APMRN website, www.capstrans.edu.au/apmrn.

Poonia, D. S. (Joint Secretary, Ministry of Labour. India) (2003). Personal Communication, New Delhi, 8 January.

Prakash, B. A. (2000). 'Exodus of Gulf Emigrants Return Emigrants of Varkala Town in Kerala' Economic and Political Weekly December 1622 2000, Vol XXXV No 51, pp. 4534-4540.

Premi, M. K. (1998). 'Impact of Internal Migration in India on the Dynamics of International Migration' in Appleyard, R. (ed), Emigration Dynamics in Developing Countries, Volume One: South Asia, Aldershot: Ashgate.

Resource Development Consultants (RDC) (1997). Study on Migrant Worker: A literature survey and identification of data needs \& policy actions, Prepared for the Ministry of Finance and Planning, Department of National Planning, Employment and Policy Planning Unit, Final Report Unpublished.

Rodriguez, R. M. (2002). 'The role of the labor sending state in the global economy: A perspective from the Philippines', in B. Carino and 
K. Lyon (eds), Proceedings of the $4^{\text {th }}$ International APMRN Conference, Manila 2001: Selected papers, Wollongong; University of Wollongong, pp. 13-27.

Ruhs, M. (2002). 'Temporary Foreign Worker programmes: Policies, Adverse Consequences, and the Need to make Them Work', Center for Comparative Immigration Studies, Working Paper No. 56, University of California-Davis.

Ruhunage, L. K. (2001). 'Expansion of Welfare Facilities for Migrant Workers in Host Countries and Measures Taken to Minimize Labour Disputes', Unpublished SLBFE internal document.

Ruhunage, L. K. (DGM Research \& Foreign Relations) (2002). Personal communication, 5/12/2002, Colombo, Sri Lanka.

Saini, R, K, (1997). 'International Migration - The Indian Experience', Paper presented at the Regional Meeting of Officials of Labour Exporting Countries, 25 \& 26 March, Colombo International Hotel, Colombo, Sri Lanka.

Santiago, J. S. (2003). 'The Europol Convention and Filipino Migrant Workers' Rights: Lessons from the European Union?', in R. Iredale, C. Hawksley and S. Castles (eds), Migration in the Asia Pacific, Cheltenham, UK and Northampton, MA, USA: Edward Elgar, pp. 20118.

Sasikumar, S. K. (2001). NLI Research Studies Series No 022/2001 'International Labour Migration from Independent India', V. V. Giri National Labour Institute. NOIDA.

Scalabrini Migration Centre (2000). Asian Migration Atlas, http:// www.scalabrini.asn.au/atlas/amatlas.htm, accessed on 12 December 2002.

Sri Lanka Bureau of Foreign Employment (SLBFE) (1985). Sri Lanka Bureau of Foreign Employment Act No 21 of 1985. 
SLBFE, (1999). Statistical Handbook on Migration 1998 Sri Lanka Bureau of Foreign Employment. Colombo.

SLBFE, (2001). Statistical Handbook on Migration 2000, Sri Lanka Bureau of Foreign Employment. Colombo.

SLBFE, (2002). Action Plan Sri Lanka Bureau of Foreign Employment. Colombo.

Soysa, D. (2002a). 'The Socio Political Impact of Sri Lanka's Overseas Employment Programme', Unpublished article for the International Migrants Day Conference, 18 December, BMICH Colombo.

Soysa, D. (2002b). Personal communication, Colombo, Sri Lanka, 9 December.

Stahl, C. and Iredale, R. (2001). 'International Labour Migration in Asia: Trends and Policy Issues', Available on CAPSTRANS website, www.capstrans.edu.au

Tomas, Patricia Santo (1998). 'Enhancing the Capabilities of Emigration Countries to Protect Men and Women Destined for Lowskilled Employment: The case of the Philippines', Paper presented at the Technical Symposium on International Migration and Development, The Hague, Netherlands, 29 June-3 July.

United Nations (2003). Levels and Trends of International Migration to Selected Countries in Asia, ST/ESA/SER.A/218, New York: United Nations.

Watkins. F. and Nurick, R. (2002). 'Migration in South Asia in Policy and Practice: A Regional Overview', Unpublished paper.

Weerasinghe, V. K. (2000). 'Sri Lanka's pre-departure and reintegration policies', Paper presented at the Preparatory meeting for Regional 
Summit on pre-departure, post arrival and reintegration programs, 27/ 2/2000 - 29/2/2000 Kuala Lumpur.

Wickramasekera, P. (2002). Asian Labour Migration: Issues and Challenges in an Era of Globalization, International Migration Papers 57, Geneva: International Labour Office.

Yapa, L. K. (1995). 'The decision making process of international labour migration with special reference to the Sri Lankan Housemaid' MA Womens Studies Dissertation University of Colombo.

Zlotnik, H. (1998). 'The Dimensions of International Migration: International migration levels, trends and what existing data systems reveal', Paper presented at UN Technical Symposium on International Migration and Development, The Hague, 29 June-3 July. 